\title{
Labor Costs and Marginal Intra-Industry Trade: The Thailand Experience
}

\author{
Sujinda Chemsripong \\ Faculty of Business, Economics and Communications, Naresuan University, Phitsanulok, Thailand \\ Email: sujindac@hotmail.com
}

Received December 21, 2013; revised January 21, 2014; accepted January 28, 2014

Copyright (C) 2014 Sujinda Chemsripong. This is an open access article distributed under the Creative Commons Attribution License, which permits unrestricted use, distribution, and reproduction in any medium, provided the original work is properly cited. In accordance of the Creative Commons Attribution License all Copyrights (C) 2014 are reserved for SCIRP and the owner of the intellectual property Sujinda Chemsripong. All Copyright (C 2014 are guarded by law and by SCIRP as a guardian.

\section{ABSTRACT}

Thailand's international trade, exports in particular, expanded considerably after the major policy changes in 1990. According to this expansion, there was also a significant increase in intra-industry trade even though the major characteristic of Thailand trade is still inter-industry. However, intra-industry trade is hypothesized to reduce adjustment costs due to trade expansion and changes in trade compared to inter-industry trade. The main purpose of this paper is to examine the effects of increased Intra-Industry Trade (IIT) on the labor market adjustment cost, in view of the changes in Thailand's pattern of trade over the post-1990 period. The study is focused on the hypothesis that Intra-Industry Trade (IIT) expansion entails lower factor adjustment costs (Smooth Adjustment Hypothesis-SAH). A dynamic panel data approach is employed. The results suggest a negative correlation between changes in employment and Marginal Intra-Industry Trade (MIIT) and confirmation of the SAH. Given the increase in IIT as a proportion of Thailand's overall trade during the period under review, the adjustment in labor markets in the form of reduced employment from trade liberalization at that time is likely to have been less than that would have otherwise been expected.

\section{KEYWORDS}

Marginal Intra-Industry Trade (MIIT); Smooth Adjustment Hypothesis (SAH); Thailand Industry; Dynamic Panel Data (GMM-System)

\section{Introduction}

At present, the pattern of international trade has changed over time due to globalization. This change has been driven by the transformation of international trade from traditional trade to more free trade. Trade liberalization is lower if the nature of trade expansion is intra-industry trade (IIT) rather than inter-industry trade. These changes will reshape the pattern of trade and reallocation of resources in the country and in the world. Firms and industries in the country need to reshape their business, especially to reshape the production cost depending on a different market supply and demand.

The statistics from the Bank of Thailand indicated that the volume of total trade (exports plus imports) had increased over time since 1979. International trade had slightly increased during 1979-1987. A trade deficit had occurred between 1987-1998. In contrast, a trade surplus had existed between1997-2007(see Figure 1).

The major international trade partners for Thailand are the ASEAN countries members, the European (EU) countries, Japan, the United States of America, and Chi-

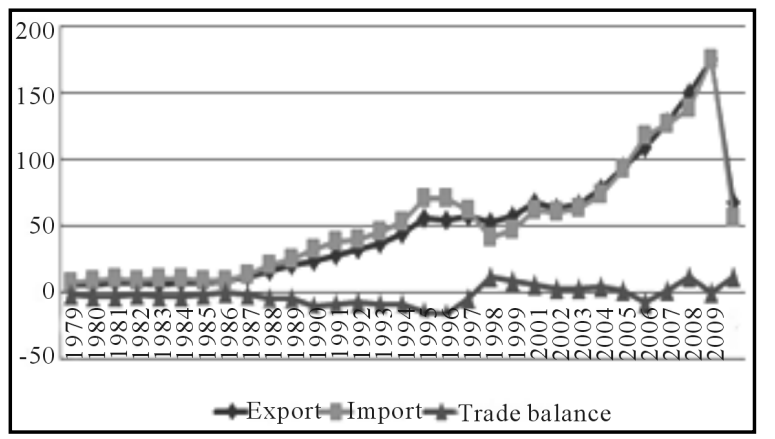

Figure 1. Export and Import Value of Thailand in 19792009, Source: Bank of Thailand. 
na. The volume of Thailand's exports exceeds imports from other countries except Japan, Taiwan and Korea (see Figure 2).

Table 1 indicates that Thailand's international trade has been dominated by the United States and Japan for many decades. However, trade with these countries has fallen from nearly 34.6 percent of Thailand's trade in 1995 to 20.79 percent in 2010. The trade with ASEAN countries has been relatively stable, increasing from 21.73 percent in 1995 and 22.7 percent in 2010. Trade within the ASEAN Economic Community (AEC) has constituted nearly 22 percent of both Thailand exports and imports. Among the country groups, therefore, the AEC with its geographical proximity and the level of economic development has been the most important group.

The share of Thailand's exports and imports with other groups namely EU (27 countries), NAFTA and the Middle East countries has been decreasing over time. As well, Thailand's share of exports and imports with countries such as the USA and Japan has been important, although it has diminished since 1995. However, the share of
Thailand imports with the ASEAN has been striking over the last a couple of years.

\section{Literature Review}

\subsection{Trade Patterns in Thailand}

ASEAN (9 countries) and the South Asia countries receive a high proportion of Thailand's exports, accounting for around 37 percent of total exports. The European countries ( 5 countries) and the USA each have 14 percent of Thailand's exports. Similarly, Korea, Japan and China each account for more than 10 percent of Thailand's exports (see Figure 3).

Figure 4 shows Thailand imports from other countries. More than 70 percent of Thailand's imports come from South Asia, Japan, ASEAN (9) and China.

Therefore, the pattern of trade expansion for Thailand has depended on the volume of total trade (exports plus imports). The study of [1] and [2] indicated that Thailand's pattern of trade measured by the G-L index has recorded an increase in intra-industry trade (IIT) [3]. The average IIT of all products in 96 items for Thailand in

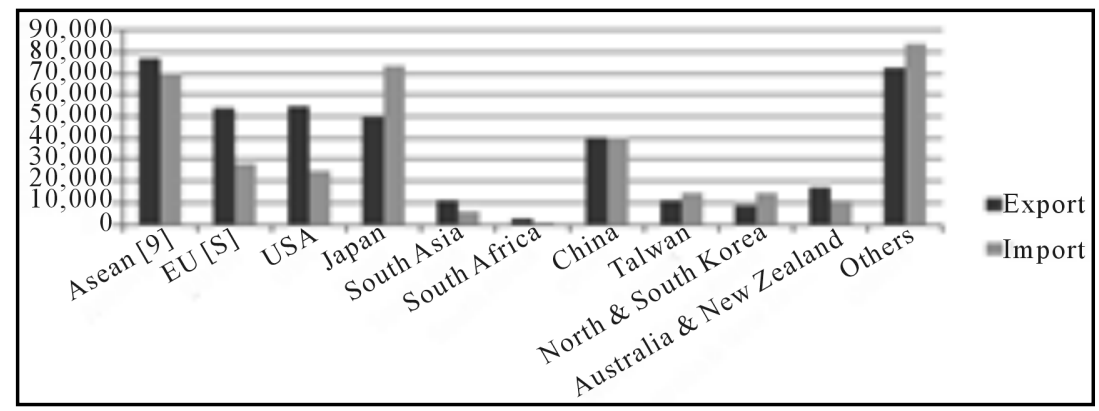

Figure 2. Export and import of Thailand with other countries, 2010.

Table 1. Thailand's trade by selected export destinations: (FoB: \% total export).

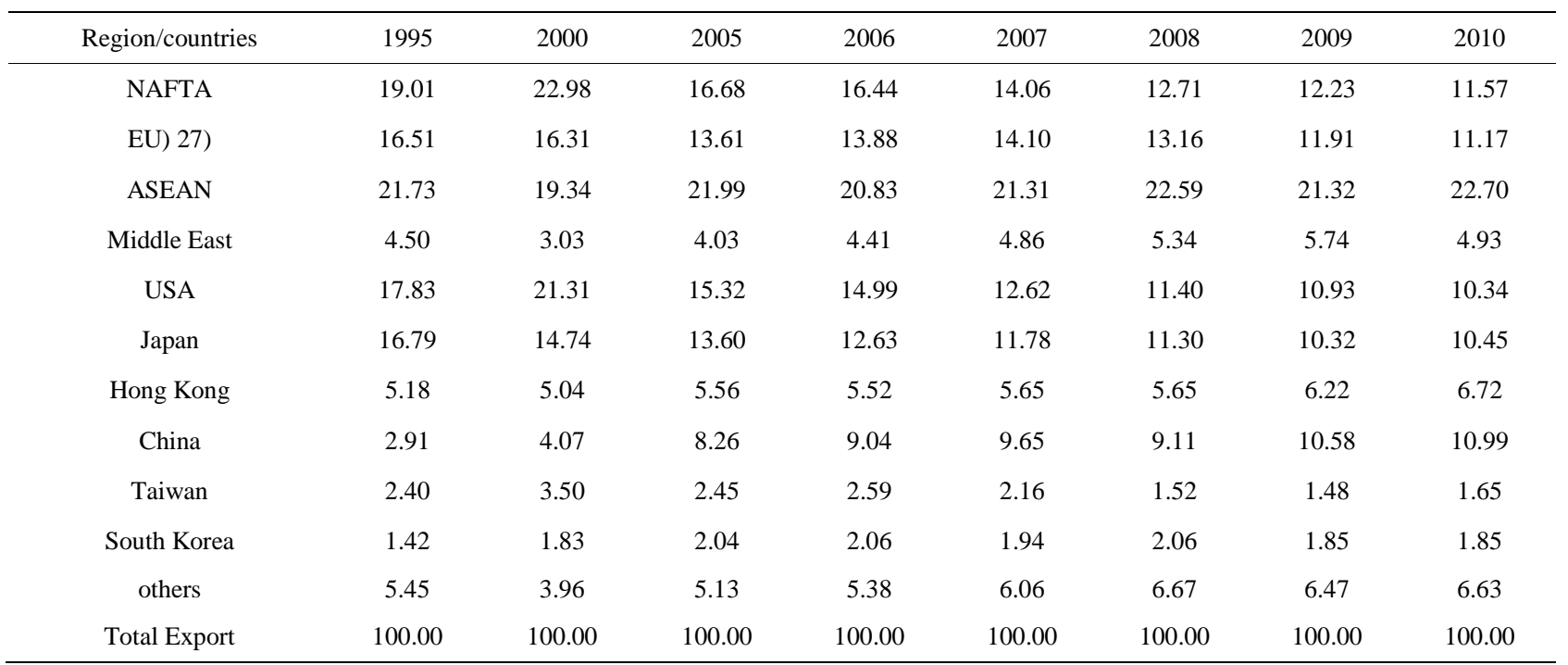

Source: Bank of Thailand. 


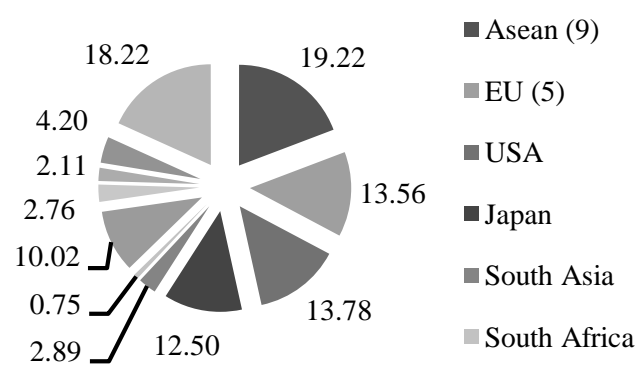

Figure 3. Export of Thailand with other countries, 2010.

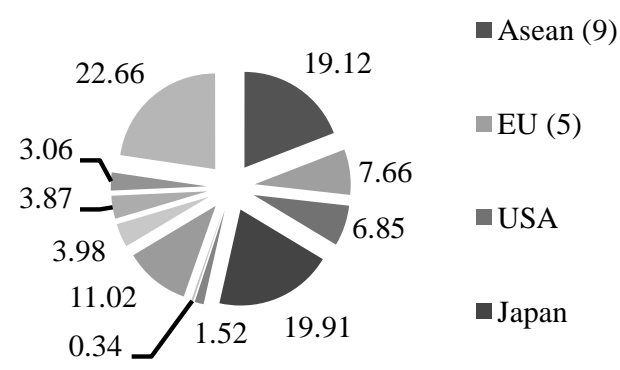

Figure 4. Import of Thailand with other countries, 2010.

2001 was 46.69 percent. The expansion of IIT increased to 53.14 in 2010. The reshaping of the labor market is lower if trade expansion is intra-industry trade (IIT) rather than inter-industry trade in nature. This is because labor can more easily mobilize to the same industry than to a different industry. This can influence the price level in the market. In fact, factor endowments e.g. labor can't freely mobilize in economy. So, IIT can measure only the level of employment to estimate the trade concentration of the adaptation pressure of trade patterns from trade expansion.

\subsection{Theoretical Basis and Empirical Studies}

The first scholar who paid attention to the reshaping of international trade was [4]. Under trade liberalization, [4] criticized the level of international trade pattern depend on the change of intra-industry trade or inter-industry trade. The IIT entails lower costs of factor market adjustment than inter-industry trade. Adjustment costs arise from temporary inefficiencies when market fails to clear instantaneously in the change of demand and supply conditions. The most important adjustment costs incurred through job search, re-location and re-training. Later, [3] invented the index measure of intra-industry trade, the so called G-L index.

$[5,6]$ argue that the G-L index proposed by Glubel \& Llyold is a static measure of the pattern of trade at a point of time. The changes of the G-L index over time do not adequately reflect the changes in trade partners. Their measure did not eliminate the scale effect. In other words, their index did not allow the comparison between industries of different size. This problem was resolved by
Marginal Intra-Industry Trade (MIIT).

The study of $[5,7,8]$ found that reducing cost adjustments involved with free trade which depend on the pattern of trade expansion being dominated by IIT rather than inter-industry trade. The cost of adjustment depends on the response of the change of demand and supply faster than the change of market adjustment in the context of changing trade environment especially in labor market which increased unemployment rate from the impact of price limited and switching costs job search relocation retraining [9]. Therefore, increased in IIT leads to reallocation in the same industry, while increased in inter-industry has the impact of reallocation of resources between industries.

Later [10] has developed the concept of changing the pattern of trade in industry lead to industry adjustment. He argued that increasing export in industry with increased import will not input mobility between the same industry. The expectation of cost adjustment will lower import differentiate labor mobility

Then [11], indicated that the correlation of IIT and free trade under the Smooth Adjustment Hypothesis (SAH) meant that an increasing proportion IIT will lead to lower cost adjustments of inputs, especially in the labor market [11]. So that trade adjustments in the form of IIT will lead to labor movements within industries more than across industries. Although today the measurement of the correlation of IIT and inter-industry trade will have different impacts on adjustment by using difference techniques.

$[8,12]$ expand the theory by explaining that according to the Smooth Adjustment Hypothesis (SAH), when IIT expands in nature there will be a reallocation of resources. However, a review of the literature indicated that the impact of resource reallocation depends on the empirical model of each country. While this research has broadly been interested in researching the costs of adjustment from changing patterns of international trade, none of research studies to date has used the theory in the context of Thailand.

Literature on trade induced labor market adjustment and on East Asian IIT has some serious limitations for three reasons:

1) Most research has studied developed countries such as OECD countries, rather than developing countries.

2) Most research has used Glubel \& Llyold's (G-L) index to explain the changed pattern of trade. However, [5] have argued that such a static measure as the Glubel \& Llyold (G-L) index is not inherently related to changes in trade and specialization, and suggest the use of the alternative measure of MIIT. So, [5] applied Marginal Intra-Industry Trade: (MIIT) instead of IIT. Therefore, G-L indices are complemented with a measure of MIIT.

3)The smooth-adjustment hypothesis: (SAH), both in 
G-L and in the MIIT version, have rarely been subjected to explicit tests due to SAH is a part of G-L index and MIIT which both index can't proof the impact of free trade with the result above.

So, this research studies the correlation between IIT and inter-industry trade by using Smooth Adjustment Hypothesis (SAH) to examine the impact from international free trade since 1990. However, expansion of IIT for Thailand will adjusted labor market for proposing policy implication for the future.

The remainder of this paper is organized as follows. The next section addresses discussion of econometric model, empirical results, and conclusion. Details of the dynamic panel data approach employed and the model specification are provided together with the empirical results and discussion.

\section{Econometric Model}

The current study applies a dynamic panel approach. The generalized method of moments (GMM) system estimator will be applied to solve the problems of serial correlation, heteroskedasticity and endogeneity among explanatory variables which can arise in static panel data models. A system of equations in both first-differences (with the lagged level as instruments) and levels (with lagged first difference of the series used as instruments) are combined.

\subsection{Dependent Variables}

The industry-level employment changes are considered as an inverse proxy for adjustment costs. [11] has suggested using the absolute value of employment changes in a particular industry $(\Delta L)$ since expected changes in total employment would be indeterminate in the specified model. According to the SAH it is expected that $(\Delta L)$ will be negatively related to MIIT. The variable is defined as follows:

$$
\Delta L=2 x \frac{\left(L_{t}-L_{t-1}\right)}{\left(L_{t}+L_{t-1}\right)}
$$

Explanatory variables and development of hypothesis follow the research literature. Four hypotheses have been proposed in the study as the following:

Hypothesis 1: There is a positive correlation between the change in obvious consumption and the change in employment. Given that $\Delta C$ as the absolute value of the change in obvious consumption between $t$ and $t-n$, $Q$ being output in the Consumption Equation as following:

$$
C=Q+M-X
$$

where $\Delta C=$ the absolute value of the change in apparent consumption, $Q=$ output of industries, $M=$ value of imports, $X=$ value of exports.

Empirical study found the positive correlation between consumption and employment. [13] found a positive relationship when the author analyzed the effects of association in the Hungarian food industry. [14] also found a positive sign in the case of Malaysia.

Hypothesis 2: There is an ambiguous sign between the change in labor productivity and the change in sector employment. Labor productivity increases lead to labor substitution or indicate that industry expansion will result in an expansion of labor employment. So using the variable $\Delta P$ is the absolute value of changing labor productivity at the industry level. [15] found a negative sign for Turkey and [9] found a negative sign for Hungarian and Poland while [14] found a positive sign for Malaysia case. We apply $\Delta P$ as absolute value of the change in labor productivity at industry level.

Hypothesis 3: Marginal intra-industry trade (MIIT) has the lower the adjustment cost. We apply MIIT (marginal intra-industry trade) as a measured by the index of MIIT, which has a negative correlation with employment. The MIIT index takes the value 0 and 1 . The value 0 indicates that the marginal trade in the industry is exclusively of the inter-industry trade and the value 1 represents that the marginal trade is entirely of the intra-industry trade.

$$
M I T=1-\frac{[\Delta X-\Delta M]}{[\Delta X]+[\Delta M]}
$$

where $M I I T=$ Marginal intra-industry, $[\Delta X-\Delta M]$ $=$ the difference of export and import value, $[\Delta X]+[\Delta M]$ $=$ the sum of difference export and import value.

According to smooth adjustment hypothesis (SAH) [11], the relationship between MIIT and the change in employment has a negative relationship and reflex the lower adjustment costs.

Hypothesis 4: The openness of international trade influences the competitiveness of firm. We apply $T$ as the absolute value of the change in exports and imports between $t$ and $t-n$. There is a positive relationship between trade and the changes of employment. Increased trade will induce enhanced competition and hence increased structural adjustment pressures on firms [11]. There is a positive relationship between trade openness and employment. [16] found a positive sign in the Portuguese case. [13] found a positive sign.

Model Specification

$$
\begin{aligned}
\log [\Delta l]_{i t}= & \beta_{0}+\beta_{1} \log [\Delta L]_{i t-1}+\beta_{2} \log \Delta C+\beta_{3} \log \Delta P \\
& +\beta_{4} \log M I I T+\beta_{5} \log T+\eta_{t} \varepsilon_{i t}
\end{aligned}
$$

where $[\Delta l]_{t}$ is absolute value of employment changes, $C$ is domestic consumption, $P$ is labor productivity (output per worker) and $T$ is imports plus exports as a share of production as a proxy for trade openness. MIIT stands 
for matched trade changes as measured by the GL index defined above. All variables are in the natural logarithm form; $\eta_{t}$ is the unobserved time-invariant specific effects, $\varepsilon_{i t}$ is a random disturbance assumed to be normal, and identically distributed with $E\left(\varepsilon_{i t}\right)=0 ; \operatorname{Var}\left(\varepsilon_{i t}\right)=\sigma^{2}>0$.

\subsection{Data}

All data are obtained from the World Bank trade and production database, Bank of Thailand (BoT), Thailand National Statistic Official (TNSO). The data includes the manufacturing sector and is at the industry level as measured at the four-digit level of the international standard industry classification (ISIC) in US dollars. The full sample contains120 industries and covers the period, 2002-2011.

\section{Empirical Results}

Table 2 provides information about the variables involved: It appears that there is heterogeneity of the variables especially for $\log [\Delta L]$ and $\log M I I T$. Thus, the estimation methodology should treat the bias that can be induced by such diversity in the data. In Table 3 we can observe the adjustment costs using OLS with time dummies for all periods (2002-2011). The present analysis evaluates the signs of the coefficients and their significance.
Three explanatory variables are significant $\left(\log [\Delta L]_{t-1}\right.$ at $1 \%, \log \Delta P$ at $1 \%, \log \Delta C$ at $5 \%$ ).

The lagged dependent variable $\log [\Delta L]_{t-1}$ is positive, which is consistent with the findings of [13] and [15]. The absolute value of the change in apparent consumption ( $\log \Delta C$ ) presents a positive sign although this result was not expected $[8,15]$. [13] found a negative correlation with this proxy and change of employment. According to the study of [13-15] we can consider that the relationship between the absolute value of the change in labor productivity and the change in employment is ambiguous. [15] found a negative sign. The study of [13] finds a positive sign. The variable $\Delta P$ presents a positive sign.

The variable market structure presents a positive correlation as expected i.e. the minimum efficient scale $(\log \Delta P)$, is positively associated with employment changes. In other words, competitiveness encourages a large number of firms and increasing openness of trade. According to the SAH, we expect a negative correlation between MIIT and the change of employment. We find the expected sign which indicates that the higher level of MIIT causes lower adjustment costs. Following [8] and [15] we introduce one trade control variable $(\log T)$. [8] expect a positive correlation between trade and employment change, since increased international trade $(\log T$ ) per-

Table 2. IIT and adjustment costs descriptive statistics.

\begin{tabular}{cccccc}
\hline Variable & Observation & Mean & Std. Dev. & Minimum & -3.19 \\
\hline $\log \Delta L$ & 120 & -1.39817 & 0.541441 & -0.35 \\
$\log |\Delta L|_{t-1}$ & 120 & 0.02591 & 0.644904 & -1.96 \\
$\log \Delta C$ & 120 & 3.75925 & 0.548548 & 0.55 \\
$\log \Delta P$ & 120 & 0.88891 & 0.388548 & -0.14 \\
$\log M I I T$ & 120 & 0.07 & 0.101622 & -0.2 \\
$\log T$ & 120 & 4.574 & 0.332301 & 0.11 \\
\hline
\end{tabular}

Fixed — effects (within) regression number of observation = 120, Group variable: industry Number of groups $=12.0$, R-square: within $=0.5547$, Observation per group: minimum $=10.0$, between $=0.2557$, Average $=10.0$, overall $=0.4614$, maximum $=10.0, F(5,103)=25.66$, corr $\left(u \_i, X b\right)=0.0522$, Prob $>F=0.0000$.

Table 3. IIT and adjustment costs, OLS estimator with time dummies for all periods.

\begin{tabular}{cccccccc}
\hline Variable & OLS & Std. Err. & $\mathrm{t}$ & $P>|t|$ & [95\% Conf. Interval] & sig \\
\hline $\log |\Delta L|_{t-1}$ & 0.4632 & 0.0486 & 9.52 & 0.000 & 0.3667 & 0.5597 \\
$\log \Delta C$ & -0.2182 & 0.1092 & -2.00 & 0.048 & -0.4349 & -0.0016 \\
$\log \Delta P$ & 0.3319 & 0.0856 & 3.87 & 0.000 & 0.1620 & 0.5019 \\
$\log M I I T$ & -0.4474 & 0.3501 & -1.28 & 0.204 & -0.2470 & 1.1419 \\
$\log T$ & 0.1903 & 0.1932 & 0.98 & 0.327 & -0.1929 & 0.5736 \\
constant & -1.7583 & 0.5861 & -3.00 & 0.003 & -2.9209 & -0.5957 \\
+
\end{tabular}

Note: Nalyzed by STATA/SE 11.0 program, sigma_ $u=0.2539$, sigma_e $\mid 0.3372$ rho $\mid 0.3618$ (fraction of variance due to u_i) $\mathrm{F}$ test that all u_i $=0$ :F(11, 103) = 5.62, Prob $>$ F $=0.0000,{ }^{* * *}$ Statistically Significant at $1 \%$ (Level 99\%), ${ }^{* *}$ Statistically Significant at 5\% (Level 95\%),

$\log [\Delta L]_{t}=$ constant $+\log [\Delta L]_{t-1}+\log \Delta C+\log \Delta P+\log M I I T+\log T+a_{i}+\varepsilon_{i t} \quad, \quad \log [\Delta L]_{t}=-1.758+0.463 \log [\Delta L]_{t}-0.218 \log \Delta C+0.332 \log \Delta P-0.447 \quad$, $\log M I I T+0.190 \log T+0.254 a_{i}+0.337 \varepsilon_{i t}$. 
mits firms and industries to increase competitiveness. The present result validates this hypothesis. [11] analyzed the relationship between SAH and the MIIT index. The author concludes that the results are better based on yearly changes.

\section{Conclusion}

The objective of this study was to analyze labor market adjustment and IIT in the manufacturing factor in Thailand. Comparing our findings with other empirical studies, we obtained similar results. Econometric estimations supported the hypotheses formulated. Present results are robust for all periods (2002-2011).

The variable $(\log \Delta C$ ) used to evaluate changes in apparent consumption between trade presents a positive correlation with changes of employment. This result is contradictory to previous studies. Present results show that there are higher changes in apparent consumption between Thailand and trading partners.

In the relationship with the variable change for labor productivity ( $\log \Delta P$ ), we find a positive sign. Using all periods (2002-2011), we find that market structure has negative and significant effects on the implicit adjustment cost. We also find a negative relationship between MIIT and the absolute employment changes. This result accords with the predictions of SAH. The correlation between trade openness and employment changes is also according to the hypothesis formulated.

However, this study has some limitations. The study needs to research on vertical and horizontal MIIT because it can be shown the two-way trade of different endowments and quality products [17]. On the other hand, the study will use a different method to estimate labor cost such as the method proposed by $[18,19]$ to solve some econometric problems such as endogeneity of some explanatory variable.

\section{Acknowledgements}

The author is indebted to the anonymous referee for various valuable suggestions.

\section{REFERENCES}

[1] S. Chemsripong, "Economic Analysis of Intra-Industry Trade between Thailand and Other APEC Countries, 19901999," Naresuan University Journal, Vol. 12, No. 3, 2004, pp. 27-42.

[2] S. Chemsripong, et al., "Regional Integration and IntraIndustry Trade in Manufactures between Thailand and Other APEC Countries," The Singapore Economic Review, Vol. 54, No. 1, 2009, pp. 135-148. http://dx.doi.org/10.1142/S0217590809003148

[3] H. Grubel and P. Lloyd, "Intra-Industry Trade: The Theory and Measurement of International Trade in Differentiated
Products,” The Mcmillian Press, London, 1975.

[4] B. Balassa "Tariff Reduction and Trade in Manufactures among Industrial Country,” American Economic Review, Vol. 56, No. 3, 1966, pp. 466-473.

[5] C. Hamilton and P. Kniest, "Trade Liberalisation, structural Adjustment and Intra-Industry Trade: A Note," Weltwirtschaftliches Archiv, Vol. 127, No. 2, 1991, pp. 356-367. http://dx.doi.org/10.1007/BF02707991

[6] J. Menon and P. B. Dixon, "Intra-Industry versus InterIndustry Trade: Relevance for Adjustment Costs,” Weltwirtschaftliches Archiv, Vol. 133, No. 1, 1997, pp. 164169. http://dx.doi.org/10.1007/BF02707682

[7] D. Greenaway, R. C. Hine, C. Milner and R. Elliott, "Adjustment and the Measurement of Marginal Intra-Industry Trade,” Weltwirtschaftliches Archiv, Vol. 130, No. 2, 1994, pp. 418-437. http://dx.doi.org/10.1007/BF02707717

[8] M. Brulhart and R. J. R. Elliott, "Labour-Market Effects of Intra Industry Trade: Evidence for the United Kingdom," Weltwirtschaftliches Archiv, Vol. 138, No. 2, 2002, pp. 207-228. http://dx.doi.org/10.1007/BF02707742

[9] I. Ferto and A. K. Soors, "Marginal Intra-Industry Trade and Adjustment Costs in the First Phase of Transition: A Hungarian-Polish Comparison,” Journal of Economics Studies, Vol. 37, No. 5, 2010, pp. 495-504. http://dx.doi.org/10.1108/01443581011075433

[10] M. Brulhart, "Marginal Intra Industry Trade: Measurement and Relevance for the Pattern of Industrial Adjustment," Weltwirtschaftliches Archiv, Vol. 130, No. 3, 1994, pp. 600-613. http://dx.doi.org/10.1007/BF02707615

[11] M. Brulhart, "Dynamics of Intra Industry Trade and Labor-Market Adjustments," Review of International Economics, Vol. 8, No. 3, 2000, pp. 420-435. http://dx.doi.org/10.1111/1467-9396.00232

[12] M. E. Lovely and D. Nelson, "Marginal Intraindustry Trade and Labour Adjustment," Review of International Economic, Vol. 8, No. 3, 2000, pp. 436-447.

[13] I. Ferto, "Labour Market Adjustment and Intra-Industry Trade: The Effects of Association on Hungarian Food Industry," Journal of Agricultural Economics, Vol. 60, No. 3, 2009, pp. 668-681. http://dx.doi.org/10.1111/j.1477-9552.2009.00201.x

[14] M. Brulhart and M. Thorpe, "Intra-Industry Trade and Adjustment in Malaysia: Puzzling Evidence,” Applied Economics Letters, Vol. 7, No. 11, 2000, pp. 729-733. http://dx.doi.org/10.1080/135048500421368

[15] G. Erlart and H. Erlat, "Intra-Industry Trade and Labor Market Adjustment in Turkey: Another Piece of Puzzling Evidence,” Emerging Markets Finance and Trade, Vol. 42, No. 5, 2006, pp. 5-27. http://dx.doi.org/10.2753/REE1540-496X420501

[16] M. Cabral and J. Silva, "Intra-Industry Trade Expansion and Employment Reallocation between Sectors and Occupations," Review of World Economics, Vol. 142, No. 3, 2006, pp. 496-520. http://dx.doi.org/10.1007/s10290-006-0078-4

[17] A. K. M. Azhar and R. J. R. Elliott, “On the Measurement of Changes in Product Qualityin Marginal Intra Industry 
Trade," Review of World Economics, Vol. 144, No. 2, 2008, pp. 225-247.

http://dx.doi.org/10.1007/s10290-008-0145-0

[18] R. Blundell and S. Bond, "Initial Conditions and Moment Restrictions in Dynamic Panel Data Models,” Journal of Econometrics, Vol. 87, No. 1, 1998, pp. 115-143.
http://dx.doi.org/10.1016/S0304-4076(98)00009-8

[19] R. Blundell and S. Bond, "GMM Estimation with Persistent Panel Data: An Applications to Production Functions," Economics Review, Vol. 19, No. 3, 2000, pp. 321340. http://dx.doi.org/10.1080/07474930008800475 